\title{
Laparoscopic Diagnosis and Treatment of a Twisted Accessory Liver Lobe
}

\author{
Antonio Sommariva, MD, Sandro Pasquali, MD, Roberto Stramare, MD, \\ Maria Cristina Montesco, MD, Saveria Tropea, MD, Carlo Riccardo Rossi, MD \\ Melanoma and Sarcomas Unit, Veneto Institute of Oncology IOV-IRCCS, Padova, Italy \\ (Drs. Sommariva, Tropea, Rossi). \\ Department of Surgery, Oncology and Gastroenterology, University of Padova, Padova, Italy (Dr. Pasquali). \\ Department of Medical Diagnostic Sciences and Special Therapies, University of Padova, Padova, Italy (Dr. Stramare). \\ Pathology Unit, Veneto Institute of Oncology IOV—IRCCS, Padova, Italy (Dr. Montesco).
}

\begin{abstract}
Accessory liver lobe (ALL) is a rare congenital abnormality characterized by the presence of hepatic tissue outside of, but attached to, the liver. ALL is usually asymptomatic, but in the case of torsion, it can be confused with an acute surgical emergency or a tumoral mass. Conventional imaging is often inconclusive, and diagnosis is generally made during laparotomy. We report the case of a patient with left ALL torsion who, for the first time, was successfully diagnosed and treated with a laparoscopic resection.
\end{abstract}

Key Words: Congenital abnormalities, Laparoscopy, Liver, Radiology.

Citation Sommariva A, Pasquali S, Stramare R, Montesco MC, Tropea S, Rossi CR. Laparoscopic diagnosis and treatment of a twisted accessory liver lobe. CRSLS e2014.00170. DOI: 10.4293/CRSLS.2014.00170.

Copyright $\odot 2014$ SLS This is an open-access article distributed under the terms of the Creative Commons Attribution-Noncommercial-ShareAlike 3.0 Unported license, which permits unrestricted noncommercial use, distribution, and reproduction in any medium, provided the original author and source are credited.

Address correspondence to: Antonio Sommariva, MD, Melanoma and Sarcomas Unit, Veneto Institute of Oncology IOV-IRCCS, Padova, Italy, via Gattamelata 64, 35128, Padova, Italy. Telephone: +390498212137, Fax: +390498218349, E-mail: antonio.sommariva@ioveneto.it

\section{INTRODUCTION}

Accessory liver lobe (ALL) is a congenital abnormality resulting from an error during the embryogenetic process of the endodermal caudal foregut at the third gestational week and is characterized by the presence of hepatic tissue outside of, but adjacent to, the liver., ${ }^{1,2}$ ALL is a rare entity, usually asymptomatic, with a reported incidence of $0.44 \% .{ }^{3}$ Among the possible complications of ALL, torsion of the pedicle is the most serious, and very few cases have been reported. ${ }^{4,5}$ Twisted ALL is associated with abdominal pain and/or impaired liver function, which may be confused with an acute surgical emergency or a tumoral mass. Imaging results are often inconclusive, and an exploratory laparotomy is generally required for a definitive diagnosis.

We present the case of a patient with left ALL torsion who was successfully treated with an elective laparoscopic resection. We have included an overview of previously reported cases of ALL.

\section{CASE DESCRIPTION}

A 21-year-old woman suddenly complained of a continuous abdominal pain in the right upper quadrant. Physical examination revealed normal temperature $\left(36.8^{\circ} \mathrm{C}\right)$, absence of abdominal distension, and no scars. At palpation, no tenderness, masses, or rebound was detected. The patient showed no abdominal distension; the abdomen was not tympanic; and bowel sounds were hyperactive. Laboratory examinations were normal. She underwent ultrasonography of the upper abdomen, which showed a 6-cm epigastric mass. After adequate pain control, the patient was discharged from the emergency department.

A week later, she underwent magnetic resonance imaging (MRI) of the upper abdomen. The MRI scan showed a mass located between the left liver lobe and the right gastric wall that was suggestive for an expansive neoformation of liver origin (Figure 1). Considering the proximity of the mass to the gastric wall, an upper endoscopic ultrasonogram was performed. This evaluation did not 


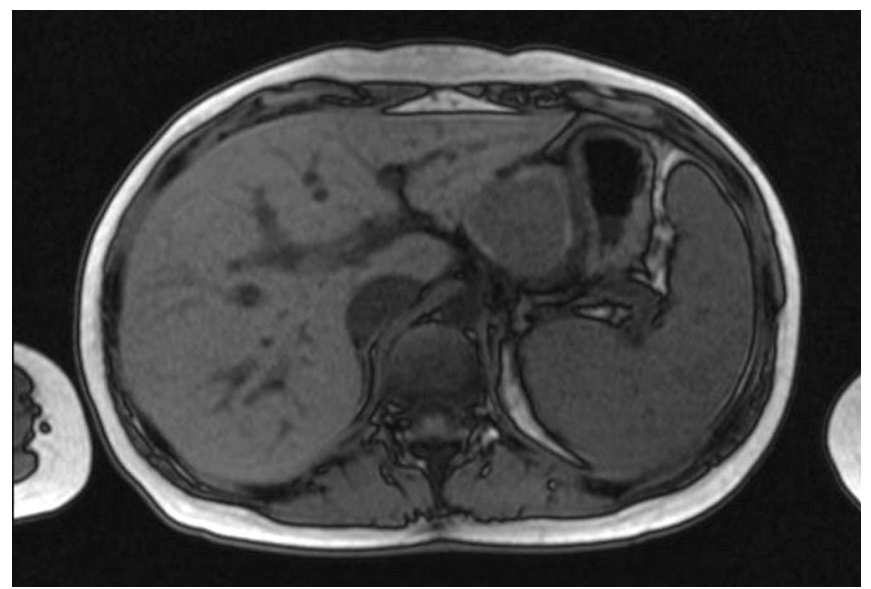

Figure 1. Magnetic resonance imaging showing a subhepatic mass

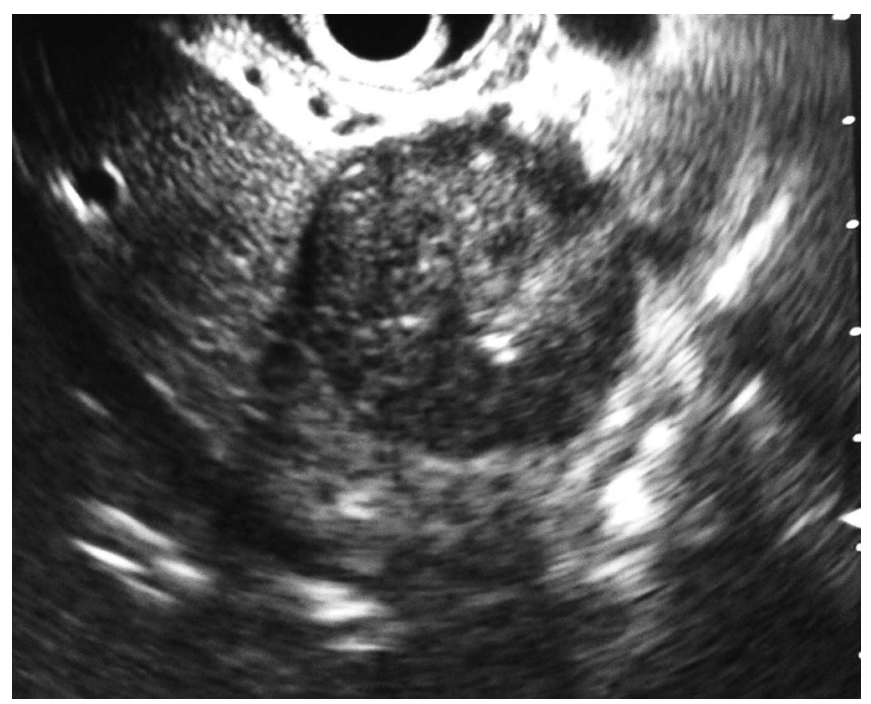

Figure 2. Endoscopic ultrasonography revealed a mass consistent with liver parenchyma, adjacent to the lesser curve of the stomach.

show any connection to the stomach, suggesting the diagnosis of a left hepatic mass (Figure 2). A computed tomography (CT) scan combined with positron emission tomography showed mildly metabolic activity on the periphery of the mass with a maximum standardized uptake value of 5.4, which is definitely not suggestive of hepatic tumor (Figure 3). During this time, the patient remained mildly symptomatic (postprandial pain), and light tenderness was detected at physical examination.

The case was evaluated during a meeting of the multidisciplinary team on soft tissue and visceral sarcomas. Expert opinion supported exploratory laparoscopy, which was accepted by the patient. After positioning the patient in

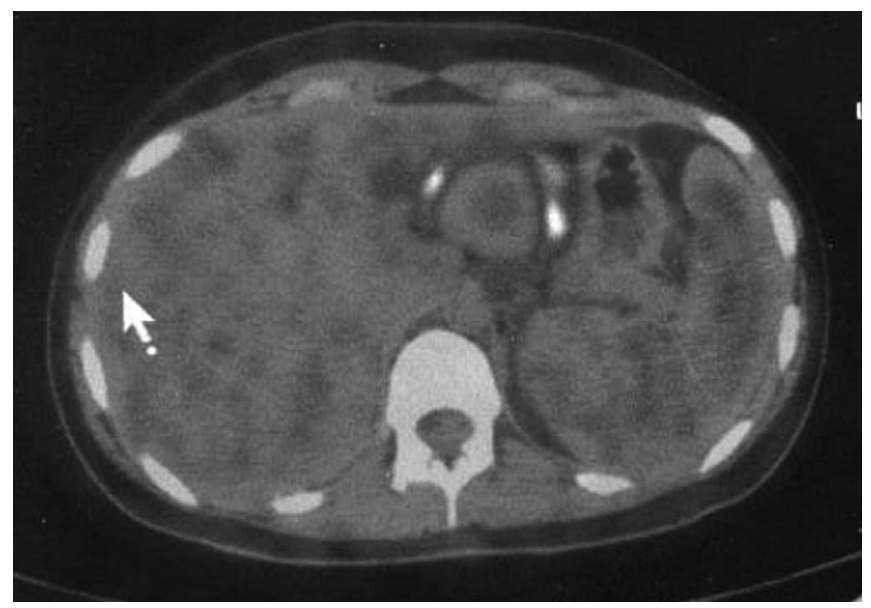

Figure 3. Positron emission tomography CT scan showed a mass between the lesser curve of the stomach and the left liver lobe.

the lithotomy position with her legs placed in stirrups, the initial $12-\mathrm{mm}$ trocar was placed via the open technique in the midline $5 \mathrm{~cm}$ cephalad to the level of the umbilicus. Once pneumoperitoneum (12 $\mathrm{mm} \mathrm{Hg}$ ) was achieved; the second and third $12-\mathrm{mm}$ trocars were symmetrically inserted on opposite sides of the abdomen, in the midclavicular line just cephalad to the level of the optical trocar. A fourth $5-\mathrm{mm}$ trocar was placed in the right anterior axillary line for liver retraction. The monitor was placed at the head of the patient on the right side, and the surgeon stood between the legs of the patient.

During laparoscopic exploration, it became evident that the mass was located inside the hepatogastric ligament and attached by a short pedicle to the second segment of the liver (Figure 4).

The mass appeared operable, and resection was performed using a 3-port access. The liver mass was dissected from the ligament tissue with an ultrasonic scalpel (Harmonic Ace, $36 \mathrm{~mm}$, Ethicon, Somerset, New Jersey) and sectioned with an endoscopic stapler (Endo Gia Autosuture Universal stapler, $12 \mathrm{~mm}$, vascular cartridge, Covidien, Mansfield, Massachusetts). The specimen was extracted from the abdominal cavity using an endobag. A tubular drain was placed under the liver for detecting and eventually treating small postoperative biliary leaks.

The postoperative course was uneventful, and the patient was discharged on the fourth postoperative day, after abdominal drain removal.

Histopathological examination of the mass showed an accessory liver lobe with signs of hemorrhagic infarction. 

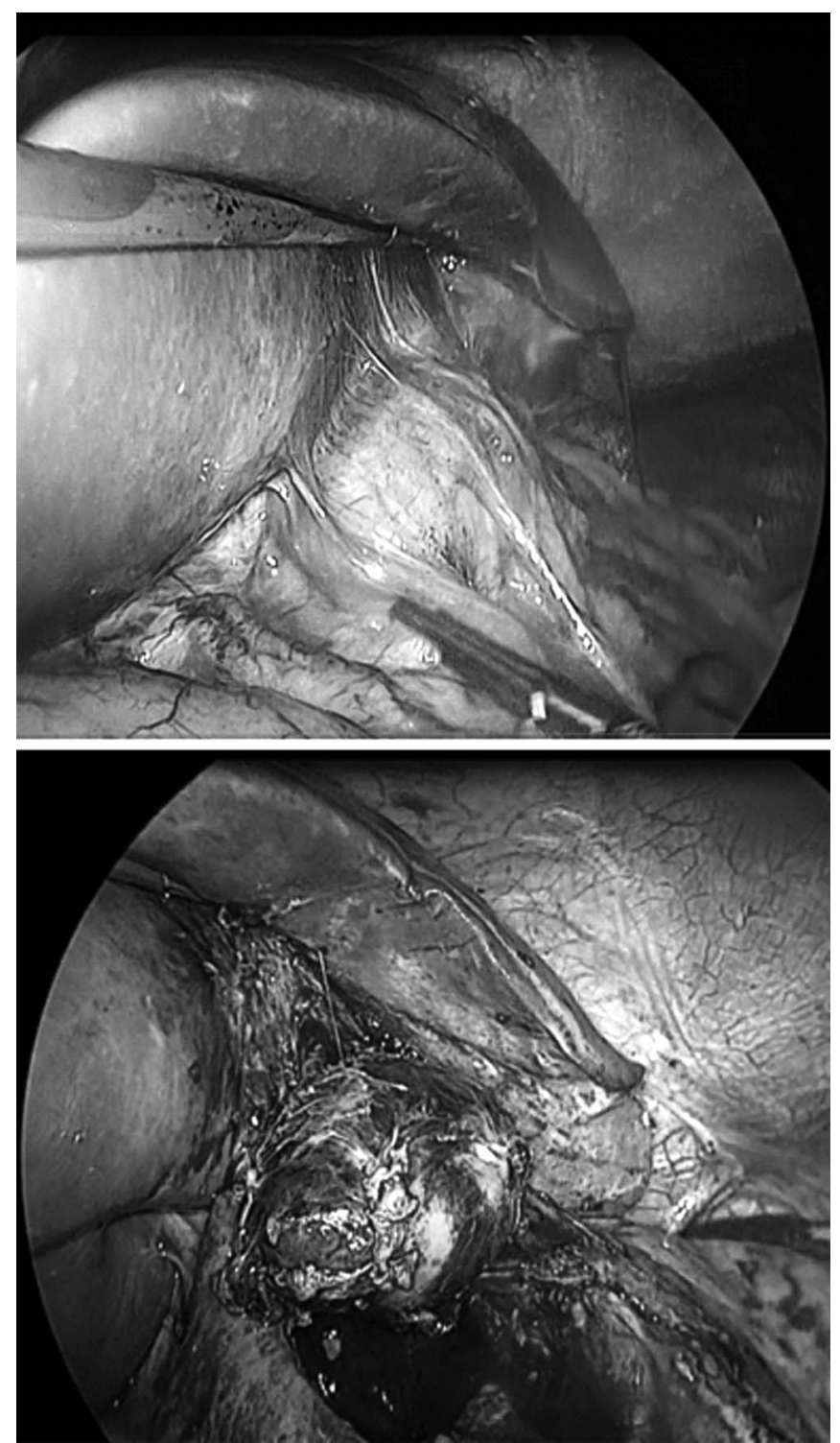

Figure 4. Laparoscopic exploration revealed the mass inside the hepatogastric ligament and connected to the liver by a bridge of liver parenchyma.

The patient underwent follow-up after 6 months with abdominal ultrasonography, which did not show any abnormalities.

Informed consent for publishing data and images was obtained from the patient.

\section{DISCUSSION}

ALL is defined as an embryological abnormality characterized by the presence of extra liver tissue connected to the liver by a bridge of hepatic tissue, a mesentery, or a stalk. If continuity with the liver is not present, this abnormality is defined as an ectopic liver. ${ }^{1,5}$ ALL is a rare entity, usually asymptomatic, and found during autopsy, surgery (laparotomy/laparoscopy), or abdominal imaging performed for other reasons. ${ }^{3,6,7}$ In a recent study on congenital anomalies of the liver observed during laparoscopic exploration, an incidence of $0.44 \%$ of ALL has been estimated. ${ }^{3}$ Potential complications of ALL, which have previously been described, are bleeding, rupture, and malignant degeneration. ${ }^{8-10}$ Torsion of ALL is rare with only 16 cases being reported (up-to-date) in the English language literature ${ }^{4,11-25}$ (Table 1).

Most twisted ALL cases were found in young females and in male infants and are often associated with abdominal wall defects.

The most common clinical presentations were acute abdominal symptoms that required surgical exploration, or as an abdominal mass, of which the differential diagnosis with a tumor appeared uncertain.

Experience on imaging of liver abnormalities has been increasing over time, and uncomplicated ALL can be easily diagnosed with CT or MRI scan, either of which allows a clear identification of the arterial and portal supply and a direct visualization of the anatomic connection to the liver. ${ }^{20-22}$

In case of a torsion of the pedicle and a consequent ALL infarction, diagnostic imaging often fails to formulate an accurate preoperative diagnosis. In twisted ALL, a contrastenhanced CT scan usually shows vascularization defects, loss of normal architecture of liver parenchyma, and uncertain origin of the mass, ${ }^{14,15}$ which may be confused with an extrahepatic tumor of pancreatic, ovarian, or peritoneal origin or an acute inflammatory condition (eg, cholecystitis and appendicitis). MRI does not offer a diagnostic advantage because the results are not specific and sometimes suggestive of a cystic mass. ${ }^{14}$ On ultrasonography, a twisted ALL appears as an hypoechogenic mass caused by congestion, and on color Doppler ultrasonography, it appears to be without vascular supply. ${ }^{11,15}$ Nuclear medicine techniques and angiography are inconclusive, as the only diagnostic sign suggestive of an infarction of ALL is lack of vascularization and viable tissue in the mass..$^{5}$ Although in our patient, the positron emission tomography CT findings were not specific, the presence of hypermetabolic tissue surrounding the mass suggested a necrotic tumor or an abscess. 


\section{Table 1.}

Published Case Reports in English Language Literature on Torsion of ALL

\begin{tabular}{|c|c|c|c|c|c|c|c|c|c|}
\hline Author & $\begin{array}{l}\text { Publication } \\
\text { Year }\end{array}$ & $\begin{array}{l}\text { Age, } \\
\text { y }\end{array}$ & Sex & $\begin{array}{l}\text { Preoperative } \\
\text { Workup }\end{array}$ & Suspected Diagnosis & $\begin{array}{l}\text { Time to } \\
\text { Treatment, } \\
\text { days }\end{array}$ & Site & Size, $\mathrm{mm}$ & Histology \\
\hline Cullen $^{11}$ & 1925 & 45 & $\mathrm{~F}$ & NR & Appendicitis & 3 & Gallbladder & $60 \times 80 \times 30$ & $\begin{array}{l}\text { Fibrous and } \\
\text { hemorrhagic tissue }\end{array}$ \\
\hline Watson and Lee ${ }^{12}$ & 1964 & 56 & $\mathrm{~F}$ & NR & Tumoral mass & 12 & Segment 1 & $48 \times 25 \times 20$ & Necrosis \\
\hline Levi et $\mathrm{al}^{13}$ & 1971 & 23 & $\mathrm{~F}$ & NR & $\begin{array}{l}\text { Ovarian/appendicular } \\
\text { abscess }\end{array}$ & NR & & 230 & Necrosis \\
\hline $\begin{array}{l}\text { Llorente and } \\
\text { Dardik }^{14}\end{array}$ & 1971 & 70 & $\mathrm{~F}$ & NR & Retroperitoneal mass & 7 & Segment 1 & $130 \times 190 \times 90$ & Postnecrotic cirrhosis \\
\hline $\begin{array}{l}\text { Omanik and } \\
\text { Jablonsky }^{15}\end{array}$ & 1972 & 29 & $\mathrm{~F}$ & NR & Mesenteric cyst & NR & Left lobe & $130 \times 120 \times 70$ & Hemorrhagic infarction \\
\hline $\begin{array}{l}\text { Pujari and } \\
\text { Deodhare }^{4}\end{array}$ & 1976 & 32 & $\mathrm{~F}$ & $\begin{array}{l}\text { Abdominal X-rays; } \\
\text { oral cholecystogram; } \\
\text { barium meal X-rays }\end{array}$ & $\begin{array}{l}\text { Cholecystitis/duodenal } \\
\text { ulcer }\end{array}$ & 21 & $\begin{array}{l}\text { Gastrohepatic } \\
\text { ligament }\end{array}$ & $50 \times 40 \times 20$ & $\begin{array}{l}\text { Dilatation of portal } \\
\text { tracts and central veins }\end{array}$ \\
\hline Grunz et $\mathrm{al}^{16}$ & 1992 & $<1$ & M & US, CT & $\begin{array}{l}\text { Gastric duplication, } \\
\text { liver hematoma, or } \\
\text { tumor }\end{array}$ & 2 & Left lobe & $29 \times 16 \times 19$ & Necrosis \\
\hline Sanguesa et al ${ }^{17}$ & 1995 & 2 & M & & Hepatic mass & 8 & $\begin{array}{l}\text { Hepatic } \\
\text { hilum }\end{array}$ & $40 \times 25$ & Necrosis \\
\hline Elmasalme et $\mathrm{al}^{18}$ & 1996 & $<1$ & M & US, CT & Abdominal mass & 14 & $\begin{array}{l}\text { Hepatic } \\
\text { hilum }\end{array}$ & $80 \times 100$ & Necrosis \\
\hline $\begin{array}{l}\text { Koumadinou et } \\
\text { al }^{19}\end{array}$ & 1998 & 12 & $\mathrm{~F}$ & US, CT, MRI & $\begin{array}{l}\text { Hepatic hematoma, } \\
\text { cystic lymphangioma, } \\
\text { echinococcus cyst, } \\
\text { gastrointestinal } \\
\text { duplication cyst }\end{array}$ & NR & Caudate lobe & 40 & NR \\
\hline Koplewitz et al ${ }^{20}$ & 1999 & 8 & $\mathrm{~F}$ & US, CT & $\begin{array}{l}\text { Post-traumatic } \\
\text { hematoma }\end{array}$ & NR & $\begin{array}{l}\text { Hepatic } \\
\text { hilum }\end{array}$ & $80 \times 80$ & NR \\
\hline Ladurner et $\mathrm{al}^{21}$ & 2005 & 19 & $\mathrm{~F}$ & CT & $\begin{array}{l}\text { Portal vein thrombosis } \\
\text { and infarction } \\
\text { accessory lobe }\end{array}$ & 1 & Segment 4 & NR & Necrosis \\
\hline $\begin{array}{l}\text { Pé́ez-Martińez et } \\
\mathrm{al}^{22}\end{array}$ & 2006 & $<1$ & M & $\begin{array}{l}\text { US, barium } \\
\text { swallow-rays }\end{array}$ & Gastric duplication & Urgent & Left lobe & NR & NR \\
\hline Umehara et $\mathrm{al}^{23}$ & 2009 & 14 & $\mathrm{~F}$ & US, CT & $\begin{array}{l}\text { Lymphangioma, } \\
\text { gastric/ } \\
\text { pancreatic tumor }\end{array}$ & 2 & Left lobe & 75 & $\begin{array}{l}\text { Congestion, } \\
\text { hemorrhage, necrosis }\end{array}$ \\
\hline Carrabetta et $\mathrm{al}^{24}$ & 2009 & 45 & M & $\begin{array}{l}\text { Abdominal X-rays, } \\
\text { CT, FNAB }\end{array}$ & NR & Urgent & Left lobe & $26 \times 16 \times 10$ & Hemorrhagic infarction \\
\hline Jambhekar et al ${ }^{25}$ & 2010 & 24 & $\mathrm{~F}$ & CT, MRI, ERCP & $\begin{array}{l}\text { Intermittent torsion of } \\
\text { ALL }\end{array}$ & 120 & Left lobe & NR & Normal liver \\
\hline Present case & 2012 & 21 & $\mathrm{~F}$ & $\begin{array}{l}\text { US, MRI, endoscopic } \\
\text { US. PET }\end{array}$ & Liver tumor & 30 & Segment 2 & $60 \times 55 \times 55$ & Hemorrhagic infarction \\
\hline
\end{tabular}

ALL, accessory liver lobe; CT, computed tomography; ERCP, endoscopic retrograde cholangiopancreatography; F, female; FNAB, fine-needle aspiration biopsy; M, male; MRI, magnetic resonance imaging; NR, not reported; PET, positron emission tomography; US, ultrasonography.

Considering these diagnostic challenges, twisted ALLs are generally diagnosed and treated during surgical exploration. In the context of a specific diagnostic algorithm, the laparoscopic exploration has been suggested as a useful tool in cases of unexplained upper abdominal pain and suspected ALL. ${ }^{5}$ The laparoscopic visualization allows a definitive diagnosis and a conservative treatment when viable tissue is demonstrated. 
In cases of torsion of ALLs, our report confirmed the diagnostic role of laparoscopic exploration; in these cases, laparoscopic resection is feasible, simple, and definitive.

Generally, laparoscopic liver resection seems to offer a significant advantage over an open approach and has been proposed for treatment of different liver conditions, especially in cases of left located masses. ${ }^{23}$ Thus, laparoscopic resection seems the most appropriate approach for ALL, as the presence of a small bridge of hepatic tissue can be easily isolated and sectioned with endosurgical staplers. In the presence of an ALL located within a different liver area, such as the caudate segment or the right lobe, or of greater volume, the laparoscopic resection may present additional operative difficulties than those in our case.

\section{CONCLUSIONS}

Diagnostic imaging is often inconclusive in cases of twisted ALLs, and laparoscopy seems the best method for a definitive diagnosis. Resection is advisable in cases of ALLs with infarction, preferably during laparoscopy as we have for the first time reported herein.

\section{References:}

1. Kostov DV, Kobakov GL. Accessory hepatic lobe. Surg Radiol Anat. 2011;33(9):819-822.

2. Bradley OC. A contribution to the morphology and development of the mammalian liver. J Anat Physiol. 1908;43(Pt 1):1-42.

3. Sato S, Watanabe M, Nagasawa S, Niigaki M, Sakai S, Akagi S. Laparoscopic observations of congenital anomalies of the liver. Gastrointest Endosc. 1998;47(2):136-140.

4. Pujari BD, Deodhare SG. Symptomatic accessory lobe of liver with a review of the literature. Postgrad Med J. 1976; 52(606):234-236.

5. Khan AM, Hundal R, Manzoor K, Dhuper S, Korsten MA. Accessory liver lobes: a diagnostic and therapeutic challenge of their torsions. Scand J Gastroenterol. 2006;41(2):125-130.

6. Sham R, Sain A, Silver L. Hypertrophic Riedel's lobe of the liver. Clin Nucl Med. 1978;3(3):79-81.

7. Gillard JH, Patel MC, Abrahams PH, Dixon AK. Riedel's lobe of the liver: fact or fiction? Clin Anat. 1998;11(1):47-49.

8. Vykouril L. An uncommon cause of acute abdomenhemorrhage into an accessory hepatic lobe[in Czech]. Rozhl Chir. 1989;68(4):253-257.

9. Garba ES, Ameh EA. Isolated rupture of an accessory liver from blunt abdominal trauma in childhood. Pediatr Surg Int. 2002;18(1):62-63.
10. Gaber M. Accessory liver containing metastatic tumour. Virchows Arch A Pathol Anat Histol. 1980;385(3):361-364.

11. Cullen T. Accessory lobe of the liver. Arch Surg. 1925;11: $718-764$.

12. Watson JR, Lee RE. Accessory lobe of the liver with infarction. Arch Surg. 1964;88:490-493.

13. Levi MM, Creque LC, Cinque S. Accessory lobe of liver presenting symptoms of pelvic tumor. N Y State J Med. 1969; 69(10):1334-1336.

14. Llorente J, Dardik H. Symptomatic accessory lobe of the liver associated with absence of the left lobe. Arch Surg. 1971; 102(3):221-223.

15. Omanik S, Jablonsky I. Pedunculated accessory hepatic lobe. Arch Surg. 1972;105(5):792-794.

16. Grunz J, Luisiri A, Cradock T. Torsion of a hepatic lobe in the neonate-ultrasound findings. Pediatr Radiol. 1992;22(3): 192-193.

17. Sanguesa C, Esteban MJ, Gomez J, Cotina H. Liver accessory lobe torsion in the infant. Pediatr Radiol. 1995;25(2):153-154.

18. Elmasalme F, Aljudaibi A, Matbouly S, Hejazi N, Zuberi MS. Torsion of an accessory lobe of the liver in an infant. $J$ Pediatr Surg. 1995;30(9):1348-1350.

19. Koumanidou C, Nasi E, Koutrouveli E, Theophanopoulou $\mathrm{M}$, et al. Torsion of an accessory hepatic lobe in a child: ultrasound, computed tomographic, and magnetic resonance imaging findings. Pediatr Surg Int. 1998;13(7):526-527.

20. Koplewitz BZ, Manson D, Ein SH. Posttraumatic torsion of accessory lobe of the liver and the gallbladder. Pediatr Radiol. 1999;29(11):799-802.

21. Ladurner R, Brandacher G, Mark W, et al. Complete hepatic ischemia due to torsion of a large accessory liver lobe: first case to require transplantation. Transpl Int. 2005;18(4):467-469.

22. Peŕez-Martińez A, Conde-Corteś J, Martińez-Bermejo MA, Bento-Bravo L. Torsion of a pedunculated accessory hepatic lobe: differential diagnosis of projectile vomiting in a neonate. $J$ Perinat Med. 2006;34(3):248-249.

23. Umehara M, Sugai M, Kudo D, Hakamada K, Sasaki M, Munakata $\mathrm{H}$. Torsion of an accessory lobe of the liver in a child: report of a case. Surg Today. 2009;39(1):80-82.

24. Carrabetta S, Piombo A, Podestà R, Auriati L. Torsion and infarction of accessory liver lobe in young man. Surgery. 2009; 145(4):448-449.

25. Jambhekar K, Pandey T, Kaushik C, Shah HR. Intermittent torsion of accessory hepatic lobe: an unusual cause of recurrent right upper quadrant pain. Indian J Radiol Imaging. 2010;20(2): $135-137$. 